\title{
Manajemen distribusi kapsul yodium pada ibu hamil di daerah endemik gangguan akibat kekurangan yodium (GAKY) di Kabupaten Gunung Kidul Provinsi Daerah Istimewa Yogyakarta
}

\author{
Hasrun Hasanu' ${ }^{1}$, Hamam Hadi ${ }^{2}$, Toto Castro ${ }^{3}$
}

\begin{abstract}
Background: lodine deficiency disorder (IDD) is a public health problem in Indonesia and this is closely related to intelligent and mental development disorder. Bad effect of IDD to pregnant mothers who suffer from serious IDD problem may happen during their second trimester pregnancy, however, such effect may be overcome by giving iodine substance supplement. Risks that may happen to pregnant mothers, especially to fetus and infants are miscarriage, stillbirth, born disabled, birth with low body weight, cretin, psychomotoric disorder, and death in infancy. According to the result of IDD mapping, Total Goiter Rate at GunungKidul District is $12.6 \%$. Short term effort to overcome IDD is distributing iodine capsule to the target, but there is problem in its implementation especially in the management process and resources.
\end{abstract}

Objectives: To determine relationship between management factor and iodine capsule distribution coverage to pregnant mothers at IDD endemic area, Gunung Kidul District.

Methods: The study was observational with cross sectional design which used both quantitative and qualitative approaches. Subjects were all nutrition staff and pregnant mothers at community health centers of IDD endemic areas at Gunung Kidul District.

Results: There was significant relationship between iodine capsule intake status and urine iodine level $\left(\chi^{2}=23.0\right.$ $p<0.001)$. This showed that iodine capsule intake status could increase urine iodine excretion level of pregnant mothers. Management process (planning, implementation, control) had significant relationship with urine iodine exrection level of pregnant mothers subsequently $\left({ }^{2}=5.4, p=0.02\right.$, $O R=1.86, \quad{ }^{2}=16.64, p<0.001, O R=2.98, \quad{ }^{2}=8.74, p=0.004$ $O R=2.23)$. This meant that good management process could increase iodine capsule intake status. Resources (human resources, facilities, fund) had significant relationship with iodine capsule intake status of pregnant mothers subsequently ( ${ }^{2}=4.65, p=0.043, O R=1.83,{ }^{2}=6.04, p=0.019$, $\left.O R=1.94, \quad{ }^{2}=6.04, p=0.019, O R=1.94\right)$. This showed that sufficient resources could increase iodine capsule intake status of pregnant mothers. lodine capsule intake status of pregnant mothers was low, i.e. 86 persons or average $35.5 \%$ out of 263 respondents and median of urine iodine exretion of pregnant mothers belonged to IDD endemic category, i.e. $86.58 \mathrm{~g} / \mathrm{L}$.

Conclusion: Management process and resources had not functioned well and there was significant relationship between management process (planning, implementation, control); and resources (staff, fund, facilities) with coverage of iodine capsule distribution to pregnant mothers. lodine capsule in- take status of pregnant mothers tended to increase urine iodine excretion level of pregnant mothers.

KEY WORDS: management, iodine capsule distribution coverage, urine iodine rate of pregnant mothers

\section{PENDAHULUAN}

Gangguan akibat kekurangan yodium (GAKY) merupakan salah satu masalah yang serius di Indonesia karena mempunyai kaitan erat dengan gangguan perkembangan mental dan kecerdasan. Di Indonesia diperkirakan masih terdapat 36,8 juta orang $(18,8 \%)$ menderita GAKY ringan, 8,2 juta (4,2\%) menderita GAKY sedang, 8,8 juta (4,5\%) menderita GAKY berat, dan 295 ribu orang cacat karena GAKY dalam bentuk kretin, bisu tuli, dan kelainan mental $(1,2,3)$.

Pada ibu hamil penderita GAKY, dampak buruk mulai terjadi pada kehamilan trimester kedua tetapi masih dapat diperbaiki apabila segera mendapat suplemen kapsul yodium. Dampak buruk yang terjadi pada janin dan bayi dapat berupa keguguran, lahir mati, lahir cacat, kretin, kelainan psikomotor, dan kematian bayi. Suplemen kapsul yodium biasanya diberikan pada awal kehamilan, namun akan lebih aman diberikan sebelum kehamilan untuk mencegah semua pengaruh defisiensi yodium sewaktu hamil $(4,5)$.

Berdasarkan survei tahun 2003 yang merupakan survei nasional untuk mengevaluasi dampak dari intensifikasi program penanggulangan GAKY, salah satu kegiatannya adalah pemberian kapsul yodium terutama pada daerah endemik berat dan sedang, khususnya pada ibu hamil, wanita usia subur, dan anak usia sekolah. Pemantauan pemberian kapsul ini masih kurang baik. Survei evaluasi tahun 2003 menemukan bahwa hanya $30 \%$ cakupan kapsul yodium yang sampai pada sasaran, sementara pada laporan program cakupan tertulis sebesar $60-75 \%(6)$.

Berdasarkan hasil survei yang dilakukan di Provinsi Daerah Istimewa Yogayakarta menunjukkan bahwa angka

\footnotetext{
Dinas Kesehatan Kabupaten Buton

2 Magister Gizi dan Kesehatan UGM, Yogyakarta

3 Bapelkes Magelang/ Fakultas Kedokteran UGM, Yogyakarta
} 
rata-rata total goiter rate (TGR) adalah 6,10\% yang tersebar di beberapa kabupaten daerah endemik. Ratarata TGR khusus untuk Kabupaten Gunung Kidul yang masih merupakan daerah endemik GAKY adalah $12,6 \%$. Ada 6 kecamatan yang merupakan daerah endemik GAKY berat dan sedang. Adapun kecamatan endemik GAKY berat (TGR $>30 \%$ ) antara lain: Kecamatan Tepus, Tanjungsari, Panggang, dan Purwosari, sedangkan kecamatan dengan endemik GAKY sedang (TGR 20$30 \%$ ) antara lain: Kecamatan Paliyan dan Saptosari $(2,7)$.

Upaya penanggulangan GAKY jangka pendek adalah dengan distribusi kapsul yodium pada daerah endemik GAKY berat dan sedang dengan sasaran wanita usia subur, ibu hamil, ibu nifas, dan anak sekolah (8). Hal ini telah dilaksanakan pada tingkat puskesmas dan posyandu dengan melibatkan lintas program dan lintas sektor. Namun dalam pelayanan program distribusi kapsul yodium masih ditemukan banyak masalah, khususnya dalam proses manajemen dan sumber daya.

Dilihat dari konsep sistem (input, process, output dan outcome), maka yang akan dianalisis dalam penelitian ini adalah proses manajemen dan sumber daya dari pelaksanaan program pendistribusian kapsul yodium pada ibu hamil sebagai suatu input dan process, status penerimaan kapsul yodium sebagai output dan kadar ekskresi yodium urin (EYU) sebagai outcome $(9,10,11)$.

Penelitian ini bertujuan untuk mengetahui manajemen program distribusi kapsul yodium pada ibu hamil di daerah endemik GAKY di Kabupaten Gunung Kidul.

\section{BAHAN DAN METODE}

Jenis penelitian ini adalah observasional dengan rancangan cross sectional. Unit analisis penelitian ini adalah puskesmas dan ibu hamil di daerah endemik GAKY Kabupaten Gunung Kidul. Pelaksana penelitian meliputi seluruh tenaga pelaksana gizi (TPG) puskesmas dan ibu hamil di daerah endemik GAKY di Kabupaten Gunung Kidul, sedangkan responden penelitian adalah 8 TPG puskesmas dan 263 orang ibu hamil di daerah endemik GAKY di Kabupaten Gunung Kidul.

Lokasi penelitian dilakukan di 6 kecamatan yang terdiri dari 8 puskesmas daerah endemik GAKY di Kabupaten Gunung Kidul. Kecamatan dan puskesmas ini dipilih karena masih merupakan daerah endemik GAKY dengan kategori endemik berat dan sedang. Besar sampel urin minimal 227 responden dan yang diperoleh selama penelitian sebanyak 263 responden ibu hamil.

Alat penelitian meliputi: kuesioner, wawancara mendalam (in-depth interview), observasi (checklist), dan survei untuk melihat status penerimaan kapsul yodium pada ibu hamil, serta pemeriksaan laboratorim kadar EYU ibu hamil dengan menggunakan metode wet digestion.
Data yang diperoleh dianalisis menggunakan program komputer. Uji chi square dengan tingkat kemaknaan $p<0,05$ digunakan untuk mengetahui hubungan antara status penerimaan kapsul yodium dengan kadar EYU, hubungan antara proses manajemen (perencanaan, pelaksanaan, pengawasan) dengan status penerimaan kapsul yodium, dan hubungan antara sumber daya (tenaga, dana, sarana) dengan status penerimaan kapsul yodium pada ibu hamil.

\section{HASIL}

\section{Karakteristik responden}

Karakteristik responden TPG meliputi: umur, jenis kelamin, pendidikan, dan lama bekerja. Berdasarkan Tabel 1, sebagian besar (87,5\%) TPG puskesmas berumur $<40$ tahun, sedangkan yang berumur $\geq 40$ tahun sebanyak $12,5 \%$. Hal ini menunjukkan bahwa TPG umumnya termasuk kelompok umur produktif. Jenis kelamin TPG pada umumnya adalah laki-laki sebanyak $75,0 \%$ dan perempuan sebanyak $25,0 \%$. Tingkat pendidikan TPG terbanyak adalah D-III Gizi/Perawat sebanyak $50,0 \%$, diikuti SPK (sekolah pendidikan keperawatan) dan D-I Gizi/Bidan masing-masing sebanyak $25,0 \%$. Lama bekerja TPG pada umumnya $\geq 5$ tahun sebanyak $87,5 \%$ dan $<5$ tahun sebanyak $12,5 \%$. TPG dengan lama bekerja $\geq 5$ tahun ini umumnya mempunyai kemampuan dan keterampilan yang hampir sama, walaupun tingkat pendidikan berbeda.

Hubungan status penerimaan kapsul yodium dengan kadar EYU pada ibu hamil di daerah endemik GAKY

Status penerimaan kapsul yodium dalam penelitian ini merupakan hasil akhir atau output dari program pendistribusian kapsul yodium pada ibu hamil. Kadar EYU

TABEL 1. Karakteristik responden TPG penelitian berdasarkan umur, jenis kelamin, pendidikan, dan lama bekerja di puskesmas daerah endemik GAKY Kabupaten Gunung Kidul

\begin{tabular}{lll}
\hline Karakteristik responden & \multicolumn{2}{c}{ Jumlah } \\
\cline { 2 - 3 } & $\mathbf{n}$ & $\%$ \\
\hline Umur & 7 & 87,5 \\
$\quad<40$ tahun & 1 & 12,5 \\
$\geq 40$ tahun & & \\
Jenis Kelamin & 6 & 75,0 \\
$\quad$ Laki-laki & 2 & 25,0 \\
$\quad$ Perempuan & & \\
Pendidikan & 2 & 25,0 \\
SPK & 2 & 25,0 \\
DI (Gizi/Bidan) & 5 & 50,0 \\
D-III (Gizi/Perawat) & & \\
Lama bekerja & 1 & 12,5 \\
$\quad<5$ tahun & 7 & 87,5 \\
$>5$ tahun &
\end{tabular}


merupakan outcome atau gambaran konsumsi yodium dari makanan sehari-hari maupun dari pemberian suplemen kapsul yodium. Hubungan antara status penerimaan kapsul yodium pada ibu hamil dan kadar EYU terlihat pada Tabel 2.

Nilai median EYU dalam penelitian ini yaitu 86,58 $\mu \mathrm{g} / \mathrm{L}$ yang menunjukkan bahwa daerah penelitian masih termasuk dalam kategori endemik GAKY. Dari 263 orang responden ibu hamil, 62 orang $(23,6 \%)$ mempunyai kadar EYU $\geq 200 \mu \mathrm{g} / \mathrm{L}, 55$ orang $(20,9 \%)$ mempunyai kadar EYU 100-199 $\mu$ g/L, 63 orang (24,0\%) mempunyai kadar EYU 50-99 $\mu$ g/L, 45 orang $(17,1 \%)$ mempunyai kadar EYU $20-49 \mu \mathrm{g} / \mathrm{L}$, dan 38 orang $(14,4 \%)$ mempunyai kadar EYU $<20 \mu \mathrm{g} / \mathrm{L}$ (Tabel 2).

Berdasarkan hasil analisis (uji chi-square) antara penerimaan kapsul yodium dengan kadar EYU pada ibu hamil terdapat hubungan bermakna $\left(\chi^{2}=23,0\right.$; $p<0,001)$.
Hubungan proses manajemen dengan status penerimaan kapsul yodium pada ibu hamil

Tabel 3 menampilkan hubungan antara proses manajemen (perencanaan, pelaksanaan, dan pengawasan) dengan status penerimaan kapsul yodium pada ibu hamil di daerah endemik GAKY di Kabupaten Gunung Kidul. Secara umum, TPG mempunyai kemampuan perencanaan dengan kategori baik sebesar 39,9\% dan kurang sebesar $60,1 \%$, sedangkan kemampuan pelaksanaan dengan kategori baik sebesar $43,7 \%$ dan kurang sebesar $56,3 \%$. Kemampuan pengawasan TPG di puskesmas daerah endemik GAKY dengan kategori baik sebesar $46,8 \%$ dan kurang sebesar $53,2 \%$.

Hasil analisis dan uji statistik menunjukkan adanya hubungan bermakna antara proses manajemen (perencanaan, pelaksanaan, dan pengawasan) dengan status penerimaan kapsul yodium pada ibu hamil, berturutturut pada proses perencanaan, pelaksanaan, dan

TABEL 2. Hubungan status penerimaan kapsul yodium dengan kadar EYU pada ibu hamil di daerah endemik GAKY Kabupaten Gunung Kidul

\begin{tabular}{|c|c|c|c|c|c|c|c|c|c|c|c|c|}
\hline \multirow{4}{*}{$\begin{array}{c}\text { Terima } \\
\text { kapsul yodium }\end{array}$} & \multicolumn{10}{|c|}{ Kadar EYU pada ibu hamil (median $\mu \mathrm{g} / \mathrm{L}$ ) } & \multirow{2}{*}{\multicolumn{2}{|c|}{ Total }} \\
\hline & \multirow{2}{*}{\multicolumn{2}{|c|}{$<20$}} & & & & & & & & & & \\
\hline & & & \multicolumn{2}{|c|}{$20-49$} & \multicolumn{2}{|c|}{$50-99$} & \multicolumn{2}{|c|}{$100-199$} & \multicolumn{2}{|c|}{$\geq 200$} & \multirow[b]{2}{*}{$\mathbf{n}$} & \multirow[b]{2}{*}{$\%$} \\
\hline & $\mathbf{n}$ & $\%$ & $\mathbf{n}$ & $\%$ & $\mathbf{n}$ & $\%$ & $\mathbf{n}$ & $\%$ & $\mathbf{n}$ & $\%$ & & \\
\hline $\mathrm{Ya}$ & 10 & 11,6 & 10 & 11,6 & 13 & 15,1 & 18 & 20,9 & 35 & 40,7 & 86 & 100 \\
\hline Tidak & 28 & 15,8 & 35 & 19,8 & 50 & 28,2 & 37 & 20,9 & 27 & 15,3 & 177 & 100 \\
\hline Total & 38 & 14,4 & 45 & 17,1 & 63 & 24,0 & 55 & 20,9 & 62 & 23,6 & 263 & 100 \\
\hline
\end{tabular}

TABEL 3. Hubungan antara proses manajemen dengan status penerimaan kapsul yodium pada ibu hamil di puskesmas daerah endemik GAKY Kabupaten Gunung Kidul

\begin{tabular}{|c|c|c|c|c|c|c|c|c|c|c|c|}
\hline \multirow{2}{*}{\multicolumn{3}{|c|}{$\begin{array}{l}\text { Proses pelaksanaan } \\
\text { manajemen }\end{array}$}} & \multicolumn{4}{|c|}{$\begin{array}{c}\text { Status penerimaan kapsul } \\
\text { yodium pada ibu hamil }\end{array}$} & \multirow{2}{*}{\multicolumn{2}{|c|}{ Total (\%) }} & \multirow{3}{*}{$x^{2}$} & \multirow{3}{*}{$\mathbf{p}$} & \multirow{3}{*}{ OR } \\
\hline & & & \multicolumn{2}{|c|}{ Tidak } & \multicolumn{2}{|c|}{ Ya } & & & & & \\
\hline Aspek & $\mathbf{n}$ & $\%$ & $\mathbf{n}$ & $\%$ & $\mathbf{n}$ & $\%$ & $\mathbf{n}$ & $\%$ & & & \\
\hline \multicolumn{12}{|c|}{ Perencanaan } \\
\hline $\begin{array}{l}\text { Kurang } \\
\text { Baik }\end{array}$ & $\begin{array}{l}158 \\
105\end{array}$ & $\begin{array}{l}60,1 \\
39,9\end{array}$ & $\begin{array}{c}115 \\
62\end{array}$ & $\begin{array}{l}72,8 \\
59,0\end{array}$ & $\begin{array}{l}43 \\
43\end{array}$ & $\begin{array}{l}27,2 \\
41,0\end{array}$ & $\begin{array}{l}158 \\
105\end{array}$ & $\begin{array}{l}100 \\
100\end{array}$ & 5,41 & $0,023^{*}$ & 1,86 \\
\hline Total & 263 & 100 & 177 & & 86 & & 263 & 100 & & & \\
\hline \multicolumn{12}{|c|}{ Pelaksanaan } \\
\hline $\begin{array}{l}\text { Kurang } \\
\text { Baik } \\
\text { Total }\end{array}$ & $\begin{array}{l}148 \\
115 \\
263\end{array}$ & $\begin{array}{r}56,3 \\
43,7 \\
100\end{array}$ & $\begin{array}{c}115 \\
62 \\
177\end{array}$ & $\begin{array}{l}77,7 \\
53,9 \\
\end{array}$ & $\begin{array}{l}33 \\
53 \\
86\end{array}$ & $\begin{array}{l}22,3 \\
46,1 \\
\end{array}$ & $\begin{array}{l}148 \\
115 \\
263\end{array}$ & $\begin{array}{l}100 \\
100 \\
100\end{array}$ & 16,64 & $0,000^{*}$ & 2,98 \\
\hline \multicolumn{12}{|c|}{ Pengawasan } \\
\hline $\begin{array}{l}\text { Kurang } \\
\text { Baik }\end{array}$ & $\begin{array}{l}123 \\
140\end{array}$ & $\begin{array}{l}46,8 \\
53,2\end{array}$ & $\begin{array}{l}94 \\
83\end{array}$ & $\begin{array}{l}76,4 \\
59,3\end{array}$ & $\begin{array}{l}29 \\
57\end{array}$ & $\begin{array}{l}23,6 \\
40,7\end{array}$ & $\begin{array}{l}123 \\
140\end{array}$ & $\begin{array}{l}100 \\
100\end{array}$ & 8,74 & $0,004^{*}$ & 2,23 \\
\hline Total & 263 & 100 & 177 & & 86 & & 263 & 100 & & & \\
\hline Total & & & & & & & 263 & 100 & & & \\
\hline
\end{tabular}


pengawasan adalah $\chi^{2}=5,41, p=0,023, O R=1,86$; ${ }^{2}=16,64, p<0,001, \mathrm{OR}=2,98 ; \quad 2=8,74, p=0,004, \mathrm{OR}=2,23$. Nilai OR pada proses perencanaan, pelaksanaan, dan pengawasan yang kurang menunjukkan bahwa puskesmas akan memiliki risiko status penerimaan kapsul yodium berturut-turut 1,86; 2,98; dan 2,23 kali lebih rendah dibandingkan dengan puskesmas yang mempunyai perencanaan, pelaksanaan, dan pengawasan yang baik (Tabel 3).

\section{Hubungan antara sumber daya dengan status penerimaan kapsul yodium pada ibu hamil}

Tabel 4 menunjukkan hubungan antara sumber daya dengan status penerimaan kapsul yodium pada ibu hamil di puskesmas daerah endemik GAKY Kabupaten Gunung Kidul. Puskesmas di daerah endemik GAKY pada umumnya mempunyai tenaga dengan kategori baik sebesar $29,7 \%$ dan kurang sebesar $70,3 \%$, sedangkan bila dilihat dari biaya operasional program distribusi kapsul yodium, puskesmas di daerah endemik GAKY yang menyatakan kurang sebesar $65,0 \%$ dan cukup sebesar $35,0 \%$. Dilihat dari kecukupan sarana, dalam hal ini adalah ketersediaan kapsul yodium dan sarana penunjang lainnya di puskesmas, puskesmas di daerah endemik GAKY yang memiliki kategori baik adalah sebesar 35,0\% dan kurang sebesar 65,0\%.

Hasil analisis dan uji statistik (uji chi square) menunjukkan adanya hubungan yang bermakna antara sumber daya (tenaga, sarana, dan dana) dengan status penerimaan kapsul yodium pada ibu hamil, berturut-turut untuk sumber daya tenaga, sarana, dan dana adalah ${ }^{2}=4,65, p=0,043, \mathrm{OR}=1,83 ;{ }^{2}=6,04, p=0,019$, $\mathrm{OR}=1,94 ; \quad{ }^{2}=6,04, \mathrm{p}=0,019, \mathrm{OR}=1,94$. Nilai OR untuk puskesmas dengan tenaga, sarana, dan dana yang kurang akan memiliki risiko status penerimaan kapsul yodium berturut-turut 1,83; 1,94; dan 1,94 kali lebih rendah dibanding puskesmas yang mempunyai tenaga, sarana, dan dana yang baik (Tabel 4).

\section{BAHASAN}

Hubungan status penerimaan kapsul yodium dengan kadar EYU pada ibu hamil di daerah endemik GAKY

Berdasarkan hasil survei yang dilakukan pada ibu hamil di 6 wilayah kecamatan yang terdiri dari 8 puskesmas daerah endemik GAKY, diperoleh hasil status penerimaan kapsul yodium, khususnya pada ibu hamil di hampir semua puskesmas masih rendah yaitu 86 orang atau rata-rata $35,5 \%$ dari 263 orang responden. Survei nasional tahun 2003 untuk mengevaluasi dampak dari intensifikasi program penanggulangan GAKY menemukan bahwa hanya $30 \%$ cakupan kapsul yodium yang sampai pada sasaran, padahal pada laporan program cakupan tertulis sebesar $60-75 \%(6)$.

Pada penelitian ini diketahui adanya hubungan yang bermakna antara penerimaan kapsul yodium dengan kadar EYU pada ibu hamil ( $\left.{ }^{2}=23,0 ; p<0,001\right)$. Hal ini dapat diartikan bahwa dengan penerimaan kapsul yodium yang baik atau tinggi ada kecenderungan dapat meningkatkan kadar EYU ibu hamil. Hal ini sesuai dengan

TABEL 4. Hubungan antara sumber daya dengan status penerimaan kapsul yodium pada ibu hamil di puskesmas daerah endemik GAKY Kabupaten Gunung Kidul

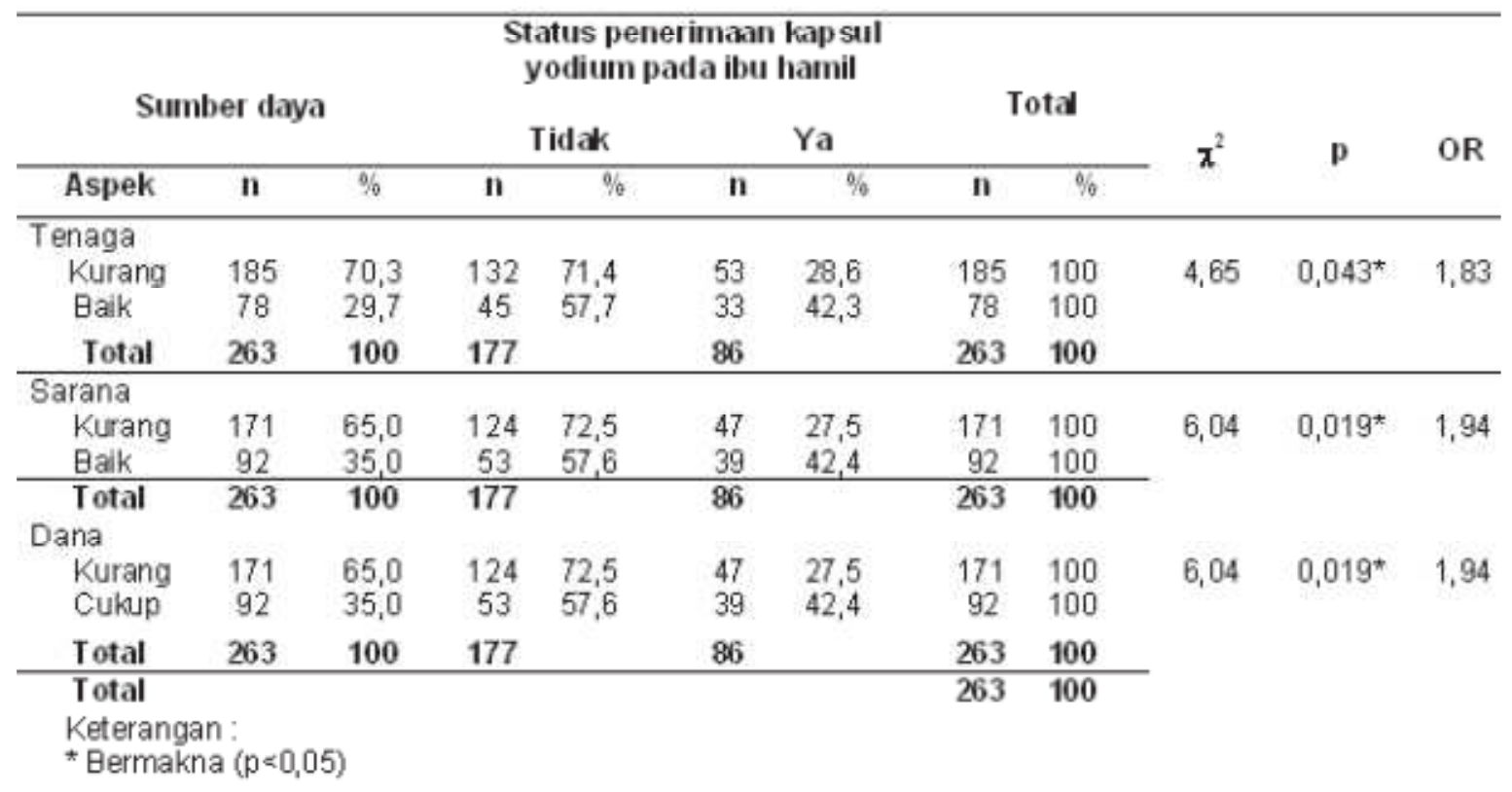


penelitian Prihatini dan Latinulu (12) yang menunjukkan bahwa jumlah yodium yang dikeluarkan melaui urin selama tiga hari pemberian kapsul yodium tidak berbeda secara bermakna antara anak gizi kurang dan gizi baik. Setelah 6 bulan pemberian kapsul yodium dengan batas kecukupan $100 \mu \mathrm{g} / \mathrm{L}$, anak gizi kurang mempunyai risiko kekurangan yodium 2,3 kali lebih besar dibanding anak gizi baik $(O R=2,3)$. Bila dilihat dari kebutuhannya $(70-$ $120 \mathrm{~g} / \mathrm{mL})$, baik pada anak gizi kurang (87 g/mL) maupun gizi baik (110 $\mathrm{g} / \mathrm{mL})$ masih berada dalam batas kecukupan. Penelitian Hadju (13) juga memperlihatkan adanya peningkatan kadar EYU secara bermakna pada setiap kelompok setelah pemberian kapsul yodium selama 1 minggu dan peningkatan yang terlihat pada kelompok perlakuan sebesar $12 \%(p=0,001)$.

Penelitian di Provinsi Maluku menunjukkan bahwa hasil analisis EYU berbeda secara bermakna antara kasus dan kontrol. Rendahnya EYU pada kelompok kasus menunjukkan bahwa kekurangan yodium adalah faktor risiko utama coastal goiter. Hal ini berarti faktor risiko utama GAKY adalah defisiensi yodium (14).

Salah satu upaya dalam menanggulangi masalah GAKY di masyarakat yaitu dengan pemberian kapsul yodium pada daerah endemik GAKY berat dan sedang. Upaya jangka pendek ini dimaksudkan untuk menjamin nutrisi yang cukup bagi seluruh penduduk, terutama bagi kelompok risiko tinggi dan mencegah gangguan retardasi mental dan fisik dan gangguan perkembangan lain yang ada hubungannya dengan GAKY. Azwar (9) mengungkapkan bahwa upaya penanggulangan GAKY jangka pendek dengan pendistribusian kapsul yodium pada kelompok sasaran telah dilaksanakan pada tingkat puskesmas dan posyandu dengan melibatkan lintas program dan lintas sektor. Manajemen pelayanan program distribusi kapsul yodium yang baik akan tergambar pada fungsi-fungsi pelaksanaan manajemen tersebut.

\section{Hubungan proses manajemen dengan status penerimaan kapsul yodium pada ibu hamil}

Proses manajemen meliputi kegiatan perencanaan, pelaksanaan, dan pengawasan. Perencanaan adalah serangkaian kegiatan untuk mempersiapkan sesuatu yang akan dilakukan secara sistematis agar program dapat terlaksana dan tujuan dapat tercapai. Secara umum TPG mempunyai kemampuan perencanaan dengan kategori baik sebesar $39,9 \%$ dan kurang sebesar $60,1 \%$. Mengacu pada kriteria dan komponen perencanaan, maka pada umumnya puskesmas tidak dapat menunjukkan dokumen perencanaan dan POA (planning, organizing, actuating). Perencanaan dikatakan baik apabila: ada kegiatan perencanaan dan bukti POA yang lengkap; POA dibuat oleh anggota pelaksana yang terlibat; dan mekanisme pembuatan rencana dimulai dengan pengumpulan data, analisis data, menetapkan jumlah sasaran sesuai dana yang tersedia.

Proses perencanaan (perhitungan jumlah sasaran dan kebutuhan) dan pengadaan kapsul yodium dilakukan oleh Dinas Kesehatan Kabupaten dengan menggunakan data proyeksi atau data estimasi berdasarkan data tahun sebelumnya. Hal ini dilakukan karena data dari sebagian puskesmas belum lengkap. Sesuai dengan penelitian Latinulu et al. (15) dalam manajemen distribusi kapsul minyak beryodium menggambarkan bahwa proses perencanaan pada tingkatan Dinas Kesehatan Kabupaten masih ada yang menggunakan data proyeksi dan hasilnya ditambah $10 \%$ untuk stok.

Pelaksanaan adalah tindakan dan peran secara sengaja yang dilaksanakan oleh orang-orang yang ada dalam organisasi dalam rangka melaksanakan program. Pada penelitian ini, pelaksanaan dalam program pendistribusian kapsul yodium oleh TPG secara keseluruhan mempunyai kategori baik sebesar $43,7 \%$ dan kurang sebesar $56,3 \%$. Pelaksanaan yang baik mempunyai kriteria: ada pembagian tugas diantara anggota tim pelaksana; ada rincian tugas untuk masingmasing yang terlibat; dan ada penetapan cara distribusi sesuai penyebaran sasaran. Sasaran tenaga yang terlibat dalam pelaksanaan distribusi kapsul yodium selain TPG adalah bidan di desa dan kader kesehatan.

Setiap puskesmas umumnya menyatakan ada pembagian tugas untuk masing-masing yang terlibat dalam program distribusi kapsul yodium pada kelompok sasaran. Namun demikian, tidak satu pun yang mempunyai bukti atau adanya dokumen yang menunjukkan tentang uraian tugas yang dimaksud. Menurut beberapa sumber, pengorganisasian mencakup kegiatan pembagian tugas di antara anggota organisasi dan pembuatan rincian tugas untuk masing-masing yang terlibat termasuk sektor yang terkait $(9,10,16,17)$. Berdasarkan uraian diatas, maka pada umumnya puskesmas di daerah endemik GAKY memiliki fungsi manajemen atau pelaksanaan dan pengorganisasian yang belum berjalan secara baik .

Pengawasan adalah pengamatan secara langsung dan berkala yang dilakukan oleh atasan terhadap bawahan dan pekerjaan yang dilaksanakan oleh bawahan $(9,10,16,17)$. Pengawasan ini dilakukan secara berjenjang. Pengawasan yang baik mempunyai kriteria: dilakukan secara berjenjang, ada obyek yang disupervisi, dan ada dokumen pengawasan dan frekuensi pengawasan lebih dari satu kali. Pelaksanaan pengawasan di puskesmas daerah endemik GAKY mempunyai kategori baik sebesar $46,8 \%$ dan kurang sebesar $53,2 \%$. Semua puskesmas 
melakukan monitoring, namun demikian tidak satu pun yang mempunyai format monitoring yang digunakan sebagai panduan kegiatan monitoring. Di samping itu juga tidak semua puskesmas mempunyai dokumen yang menunjukkan bahwa telah dilakukan pengawasan atau monitoring.

Hasil analisis dan uji statistik menunjukkan adanya hubungan bermakna antara proses manajemen (perencanaan, pelaksanaan, dan pengawasan) dengan status penerimaan kapsul yodium pada ibu hamil $(p<0,05)$. Hal ini menunjukan bahwa proses manajemen (perencanaan, pelaksanaan dan pengawasan) yang baik, ada kencenderungan dapat meningkatkan status penerimaan kapsul yodium pada ibu hamil di daerah endemik GAKY.

\section{Hubungan antara sumber daya dengan status penerimaan kapsul yodium pada ibu hamil}

Sumber daya yang diteliti dalam penelitian ini meliputi: tenaga, dana, dan saran. Tenaga adalah orang atau pegawai yang ditunjuk untuk bertanggungjawab dalam pelaksanaan program. TPG memegang peranan penting, khususnya dalam perencanaan program penanggulangan GAKY yaitu distribusi kapsul yodium pada sasaran. Tenaga dikatakan baik apabila: TPG sesuai dengan latar belakang pendidikan, TPG merupakan tugas pokok, TPG tidak merangkap lebih dari 2 program sekaligus.

Berdasarkan hasil penelitian ini, puskesmas di daerah endemik GAKY mempunyai tenaga dengan kategori baik sebesar $29,7 \%$ dan kurang sebesar $70,3 \%$. Kurangnya tenaga yang berlatar belakang pendidikan gizi pada beberapa puskesmas mengakibatkan banyak petugas yang merangkap 3-4 program sekaligus. Hal ini yang menimbulkan kinerja petugas kurang baik. Dengan demikian, tersedianya TPG khususnya yang berpendidikan D-III Gizi/Perawat dapat dimanfaatkan untuk menyusun kegiatan program distribusi kapsul yodium untuk peningkatan status penerimaan kapsul yodium pada ibu hamil.

Dana disediakan dan dipergunakan petugas dalam melaksanakan kegiatan program distribusi kapsul yodium. Bila dilihat dari besarnya biaya operasional program distribusi kapsul yodium, puskesmas di daerah endemik GAKY yang menyatakan kurang sebesar $65,0 \%$ dan baik sebesar $35,0 \%$. Pada suatu puskesmas dikatakan baik apabila tersedia: dana transportasi dari dinas ke puskesmas; dana transportasi petugas puskesmas ke sasaran atau posyandu dan biaya petugas dalam melakukan pelacakan ke rumah-rumah sasaran; serta biaya pertemuan rutin petugas pelaksana program di puskesmas. Sebagian besar responden menyatakan bahwa alokasi dana operasional untuk kegiatan program distribusi kapsul yodium masih kurang. Hal ini menunjukkan bahwa masalah biaya merupakan hambatan dalam pelaksanaan program, sehingga program yang sudah direncanakan tidak dapat terealisasi atau tercapai dengan baik. Menurut Sabarguna (18), dana atau biaya sering dipandang sebagai aspek yang diharapkan dapat memberikan dampak produktivitas setinggi-tingginya agar kelangsungan hidup organisasi dapat ditingkatkan dari waktu ke waktu. Hal ini sesuai dengan penelitian Triretnaningsih (19)yang menunjukkan bahwa sumber daya (tenaga, sarana, dan dana) akan dapat meningkatkan program perbaikan gizi di puskesmas.

Sarana adalah ketersediaan kapsul yodium dan sarana penunjang di puskesmas dengan jumlah cukup dan sesuai dengan jumlah sasaran dalam kegiatan program distribusi kapsul yodium di puskesmas. Dilihat dari kecukupan sarana, dalam hal ini adalah ketersediaan kapsul yodium dan sarana penunjang lainnya di puskesmas, puskesmas di daerah endemik GAKY yang memiliki kategori baik adalah $35,0 \%$ dan kurang sebesar $65,0 \%$. Sarana dikatakan baik apabila jumlah kapsul yodium di puskesmas tersedia dalam jumlah yang sesuai dengan jumlah sasaran.

Penelitian ini dapat memberikan gambaran bahwa sumber daya belum dilaksanakan secara maksimal dalam pelaksanaan distribusi kapsul yodium, sehingga status penerimaan sebagai output secara umum juga masih rendah. Di samping itu, terlihat ada hubungan yang bermakna antara sumber daya dengan status penerimaan kapsul yodium pada ibu hamil $(p<0,05)$. Keadaan ini memperkuat anggapan bahwa program distribusi kapsul yodium pada sasaran risiko tinggi di puskesmas daerah endemik GAKY berat dan sedang masih diperlukan. Dengan demikian, bila program distribusi kapsul yodium masih dilanjutkan, harus ada perbaikan proses manajemen dan sumber daya sehingga status penerimaan kapsul yodium dapat ditingkatkan untuk melihat keberhasilan program.

\section{KESIMPULAN DAN SARAN}

\section{Kesimpulan}

Terdapat hubungan yang bermakna antara sumber daya (tenaga, sarana, dan dana) dengan status penerimaan kapsul yodium pada ibu hamil. Puskesmas dengan sumber daya yang baik dapat meningkatkan peluang ibu hamil untuk menerima kapsul yodium.

Antara proses manajemen (perencanaan, pelaksanaan, dan pengawasan) dengan status penerimaan kapsul yodium pada ibu hamil juga terdapat hubungan yang bermakna. Puskesmas dengan proses manajemen yang baik dapat meningkatkan peluang ibu hamil untuk menerima kapsul yodium. 
Selain itu, hubungan yang bermakna juga ditemukan antara status penerimaan kapsul yodium dengan kadar EYU pada ibu hamil. Ibu hamil yang menerima kapsul yodium selama kehamilannya mempunyai kecenderungan untuk mempunyai kadar EYU lebih tinggi dibandingkan ibu hamil yang tidak menerima kapsul yodium.

\section{Saran}

Distribusi atau pemberian kapsul yodium kelompok sasaran khususnya pada ibu hamil perlu mendapat perhatian khusus dalam upaya intensifikasi penanggulangan GAKY jangka pendek pada daerah endemik GAKY berat dan sedang. Untuk itu perlu dilakukan beberapa hal.

Bagi pemerintah kabupaten atau instansi terkait (Dinas Kesehatan dan Puskesmas) dapat melakukan perbaikan proses manajemen (perencanaan, pelaksanaan, dan pengawasan) dalam pendistribusian kapsul yodium pada kelompok sasaran.

Pemberdayaan TPG secara optimal juga berperanan penting dalam peningkatan cakupan kapsul yodium pada sasaran, baik itu melalui perencanaan dan pelaksanaan distribusi kapsul, pengadaan sarana penunjang program, dan penambahan biaya operasional program pendistribusian kapsul yodium di puskesmas daerah endemik GAKY.

Perlu adanya evaluasi program intensifikasi penanggulangan GAKY khususnya pelaksanaan program distribusi kapsul yodium pada kelompok sasaran pada ibu hamil dan evaluasi prevalensi kecamatan untuk efisiensi dan efektivitas penurunan prevalensi GAKY.

\section{RUJUKAN}

1. Aritonang, Evawati Y. Dampak Defisiensi Yodium Pada Berbagai Tahapan Perkembangan Kehidupan Manusia dan Upaya Penanggulangannya [disertasi]. Bogor: Institut Pertanian Bogor; 2003.

2. Djokomoeljanto. Evaluasi Masalah Gangguan Akibat Kekurangan Yodium (GAKY) di Indonesia. Jurnal GAKY Indonesia 2002;3(2):31-4.

3. Dunn, John T. The Global Challenge of lodine Deficiency. Dalam: Redaksi Jurnal GAKY Indonesia. Kumpulan Naskah Pertemuan IImiah Nasional Gangguan Akibat Kekurangan Yodium (GAKY) 2001. Jurnal GAKY Indonesia 2001;1(1):1-7.

4. Chandra B. Pengantar Statistik Kesehatan. Palembang: Penerbit Buku Kedokteran ECG; 2000.

5. Hartono B. Perkembangan Fetus dalam Kondisi Defisiensi Yodium dan Cukup Yodium. Jurnal GAKY Indonesia 2002; 1(1):19-27.
6. Atmarita, Fallah TS. Analisis Situasi Gizi dan Kesehatan Masyarakat. Prosiding Widyakarya Nasional Pangan dan Gizi VIII. Jakarta: Direktorat Gizi Masyarakat Departemen Kesehatan RI; 2004.

7. Dinas Kesehatan Kabupaten Gunung Kidul. Profil dan Laporan Evaluasi Program Kabupaten Gunung Kidul. Wonosari: Dinkes Kabupaten Gunung Kidul;2003.

8. Departemen Kesehatan RI. Pedoman Distribusi Kapsul Minyak Beryodium bagi Wanita Usia Subur. Jakarta:Depkes Rl;1997.

9. Azwar A. Pengantar Administrasi Kesehatan. Edisi Ketiga. Jakarta: Binarupa Aksara;1996.

10. Muninjaya AAG. Manajemen Kesehatan. Edisi 2. Jakarta: Penerbit Buku Kedokteran EGC; 2004.

11. Prayitno. Dasar-Dasar Administrasi Kesehatan Masyarakat. Surabaya: Airlangga University Press; 2001.

12. Prihartini S, Syarifudin Latinulu. Pengaruh Status Gizi terhadap Kadar Yodium Urin Setelah Pemberian Kapsul Yodium pada Anak Sekolah Dasar di Daerah Gondok Endemik. Bogor: Badan Penelitian dan Pengembangan Kesehatan Departemen Kesehatan $\mathrm{Rl} ; 2002$.

13. Hadju V. Pengaruh Pemberian Obat Cacing terhadap Penyerapan Yodium pada Anak Sekolah yang Menerima Kapsul Yodium di Kabupaten Enrekang, Sulawesi Selatan. Jurnal GAKY Indonesia 2003;56(2):15-23.

14. Thaha AR, Dachlan MDj, Jafar N. Analisis Faktor Risiko Coastal Goiter. Jurnal GAKY Indonesia 2001;1(1):9-17.

15. Latinulu S, Kartika V, Budiman B, Prihartini S. Manajemen Distribusi Kapsul Minyak Beryodium di Tujuh Kabupaten di Jawa Barat dan Sumatera Selatan. Penelitian Gizi dan Makanan 2002;25(2):1-14.

16. Siagian SP. Manajemen Stratejik. Jakarta:PT Bumi Aksara; 2002.

17. Wijono D. Manajemen Mutu Pelayanan Kesehatan; Teori, Strategi dan Aplikasi. Volume 1. Surabaya: Airlangga University Press; 1999.

18. Sabarguna BS. Quality Assurance Pelayanan Rumah Sakit. Konsorsium Rumah Sakit Islam Jateng. Yogyakarta: Dinas Kesehatan Yogyakarta; 2004.

19. Triretnaningsih S. Evaluasi Mutu Perencanaan Program Perbaikan Gizi Tingkat Puskesmas Dinas Kesehatan Kota Bogor [tesis]. Yogyakarta:Universitas Gadjah Mada; 2004. 